\title{
Comparison of treatment and energy efficiency of advanced oxidation processes for the distillery wastewater
}

\author{
P. Asaithambi • R. Saravanathamizhan • \\ M. Matheswaran
}

Received: 23 November 2013/Revised: 21 January 2014/ Accepted: 19 April 2014/Published online: 15 May 2014

(C) Islamic Azad University (IAU) 2014

\begin{abstract}
The treatment of distillery effluent was investigated experimentally by various advanced oxidation processes such as Fenton and ozone with different combination of $\mathrm{UV}$ and $\mathrm{H}_{2} \mathrm{O}_{2}$ system. The effect of operating parameters such as hydrogen peroxide concentration, initial effluent $\mathrm{pH}$ and $\mathrm{Fe}^{2+}$ concentration on Fenton system for the percentage color and chemical oxygen demand removal has been studied. The energy per order was also calculated for the advanced oxidation process. The ozone-photoFenton system has been observed that $100 \%$ color and chemical oxygen demand removal compared with other process studied in the present investigation within $4 \mathrm{~h}$ of treatment time. Electrical energy per order has been calculated for all the process and found that ozone-photoFenton shows lesser energy consumption of about $0.01 \mathrm{kWh} / \mathrm{m}^{3}$ order $^{1}$, for the complete color and chemical oxygen demand removal.
\end{abstract}

Keywords Advanced oxidation processes · Distillery effluent - Color removal - Chemical oxygen demand . Electrical energy per order

\footnotetext{
P. Asaithambi · M. Matheswaran $(\square)$

Department of Chemical Engineering, National Institute of Technology, Tiruchchirappalli 620 015, Tamil Nadu, India e-mail: math_chem95@rediffmail.com

R. Saravanathamizhan

Department of Chemical Engineering, SSN College of Engineering, Rajiv Gandhi Salai, Kalavakkam 603110 , Tamil Nadu, India
}

\section{Introduction}

Distilleries are one of the most polluting industries generating large volumes of high strength wastewater. These effluents are containing highly colored, COD, BOD, TDS and other organic matter. To meet the environmental standards and regulations, treatment of effluent is must before letting out to the environment. Research has been carried out on the treatment of distilleries wastewater. Various conventional methods have been adopted such as biological flocculation (Zhang et al. 2009), nanofiltration (Rai et al. 2008), activated carbons (Satyawali and Balakrishnan 2007), bioelectrochemical process (Mohanakrishna et al. 2010), ozonation-based process (Sreethawong and Chavadej 2008; Lucas et al. 2010; Asaithambi et al. 2012), electro-oxidation (Piya-areetham et al. 2006; Thakur et al. 2009), membrane-based nanofiltration and reverse osmosis (Nataraj et al. 2006) and electrocoagulation (Ponselvan et al. 2009). However, conventional methods found to be techno-economically non-feasible for the treatment of organic pollutant present in the effluent. Hence, it is necessary to investigate an alternative process for effective and economical treatment method. Nowadays, "Advanced Oxidation Processes" (AOPs) have been received great attention for the removal of organic pollutant present in the various industrial effluents. AOPs are often employed as a pretreatment method in an integrated system and also able to enhance the biodegradability of contaminants through converting recalcitrant contaminants into smaller and consequently more biodegradable intermediates.

Various oxidation methodologies such as photocatalytic process, Fenton and photo-Fenton process and catalytic ozone process have been widely used for the treatment of effluent. The AOPs are characterized by the 
production of hydroxyl radicals which are nonselective character and are able to oxidize and mineralize most organic and inorganic pollutants to produce $\mathrm{H}_{2} \mathrm{O}, \mathrm{CO}_{2}$ and inorganic ions. (Mandal et al. 2010). However, the lifetime of $\mathrm{OH}$ is extremely short $\left(t \leq 10^{-3} \mathrm{~s}\right)$ and once the hydroxyl radicals have formed, they can give rise to several elementary reactions. The AOPs are also operated at ambient temperature. Various techniques have been adopted for the treatment of industrial effluent, but limited studies have been focused on distillery effluent treatment by AOPs. Present study focuses the decolorization and degradation of distillery effluent. Some literature shows the decolorization and degradation studies using AOP. Modirshahla and Behnajady studied the degradation of Malachite green using $\mathrm{UV} / \mathrm{H}_{2} \mathrm{O}_{2}$ process, and the result shows that $300 \mathrm{mg} / \mathrm{l}$ of $\mathrm{H}_{2} \mathrm{O}_{2}$ is the optimum dosage for the treatment. Saritha et al. (2007) compared various AOP for the degradation of 4-chloro-2-nitro phenol, and the result shows that removal rate was higher for the UV/ Fenton process. Bin and Sobera-Made (2012) studied UV, $\mathrm{UV} / \mathrm{H}_{2} \mathrm{O}_{2}$ and $\mathrm{O}_{3}$ process for the treatment of antibiotic substance present in the wastewater, and the effective removal of COD and TOC was observed for the $\mathrm{O}_{3}$ process. Grcic et al. (2010) investigated photocatalytic oxidation and Fenton oxidation process for the treatment of wastewater containing reactive azo dyes, Reactive Violet 2 and Reactive Yellow 3 and inferred that Fenton process rate is faster than the photocatalytic process. Various dye solutions like Reactive Black 5, Direct Red 28 and Direct Yellow 12 for treatment using UV, UV/ $\mathrm{H}_{2} \mathrm{O}_{2}$ and $\mathrm{UV} / \mathrm{H}_{2} \mathrm{O}_{2} / \mathrm{Fe}^{2+}$ process and reported that photoFenton process increases the decolorization and mineralization within short irradiation time by Bali et al. (2004). Few researches focused on distillery effluent treatment using AOP. Asaithambi et al. (2012) studied ozoneassisted electrocoagulation for the treatment of effluent, and they observed ozone-assisted electrocoagulation was more effective than electrocoagulation and ozonation alone. The photodegradation of effluent in the presence of solar radiation and the result shows $79 \%$ color removal under the optimum conditions of $\mathrm{H}_{2} \mathrm{O}_{2}, \mathrm{pH}$ and catalyst by Vineetha et al. (2013). Sreethawong and Chavadej (2008) experimented treatment in the presence of immobilized iron catalyst using ozonation, and the result shows that the presence of catalyst enhances the color and COD removal.

The aim of the present work was to investigate the performance of different advanced oxidation process for the color and COD removal and electrical energy per order to treat the distillery effluent. Different types of AOPs such as $\mathrm{UV} / \mathrm{H}_{2} \mathrm{O}_{2}, \mathrm{H}_{2} \mathrm{O}_{2} / \mathrm{Fe}^{2+}, \mathrm{UV} / \mathrm{H}_{2} \mathrm{O}_{2} / \mathrm{Fe}^{2+}, \mathrm{O}_{3}, \mathrm{O}_{3} / \mathrm{Fe}^{2+}, \mathrm{O}_{3} /$
$\mathrm{UV}, \mathrm{O}_{3} / \mathrm{UV} / \mathrm{H}_{2} \mathrm{O}_{2}, \mathrm{O}_{3} / \mathrm{UV} / \mathrm{Fe}^{2+}$ and $\mathrm{O}_{3} / \mathrm{UV} / \mathrm{Fe}^{2+} / \mathrm{H}_{2} \mathrm{O}_{2}$ were employed and also considering the effect of various operating parameter such as initial $\mathrm{H}_{2} \mathrm{O}_{2}$ concentration, initial $\mathrm{Fe}^{2+}$ concentration and $\mathrm{pH}$ of effluent by the system of $\mathrm{UV} / \mathrm{H}_{2} \mathrm{O}_{2}$, and electrical energy per order was also calculated. Among the different AOP , energy efficient process has been identified for the high color and COD removal of the distillery effluent.

\section{Materials and methods}

Material

The effluents are collected from nearby distillery industries. The characteristic of the effluent is shown in Table 1. All the chemicals used in the present study are purchased from Merck Company. Hydrogen peroxide $(50 \% \mathrm{w} / \mathrm{w})$ is used as oxidant reagent, iron(II) sulfate heptahydrate $\left(\mathrm{FeSO}_{4} \cdot 7 \mathrm{H}_{2} \mathrm{O}\right)$ as source of $\mathrm{Fe}^{2+}$ catalyst. Sulfuric acid and sodium hydroxides are used to adjust the $\mathrm{pH}$ of the solution, and ferrous ammonium sulfate, $\mathrm{K}_{2} \mathrm{Cr}_{2} \mathrm{O}_{7}$ and $\mathrm{Na}_{2} \mathrm{SO}_{3}$ are used for the analysis of treated solution. The double distilled water is used to prepare the entire solution.

\section{Experiment}

The experimental setup for the present investigation is shown in Fig. 1. It consists of photochemical reactor and ozone generator. The photochemical reactor made of borosilicate glass (Heber Scientific Company, Chennai) with the capacity of $600 \mathrm{ml}$. The reactor is surrounded with a water-cooling jacket to remove the heat produced by the lamp and to maintain a constant temperature. The reactor also covered with an aluminum foil to avoid light radiation to the outside. The reactor is placed on magnetic stirrer to maintain a uniform concentration. At the top of the reactor, there are inlets for feeding the effluent and a port for withdrawing samples and also monitoring

Table 1 Characteristics of wastewater

\begin{tabular}{lll}
\hline S. No. & Parameters & Range of values \\
\hline 1 & COD & $80,000-90,000 \mathrm{mg} \backslash \mathrm{L}$ \\
2 & BOD & $7,000-8,000 \mathrm{mglL}$ \\
3 & TSS & $15.44 \mathrm{glL}$ \\
4 & TDS & $5,550-5,750 \mathrm{mg} \backslash \mathrm{L}$ \\
5 & Color & Dark brown \\
6 & Odor & Burn sugar \\
\hline
\end{tabular}


Fig. 1 Experimental setup

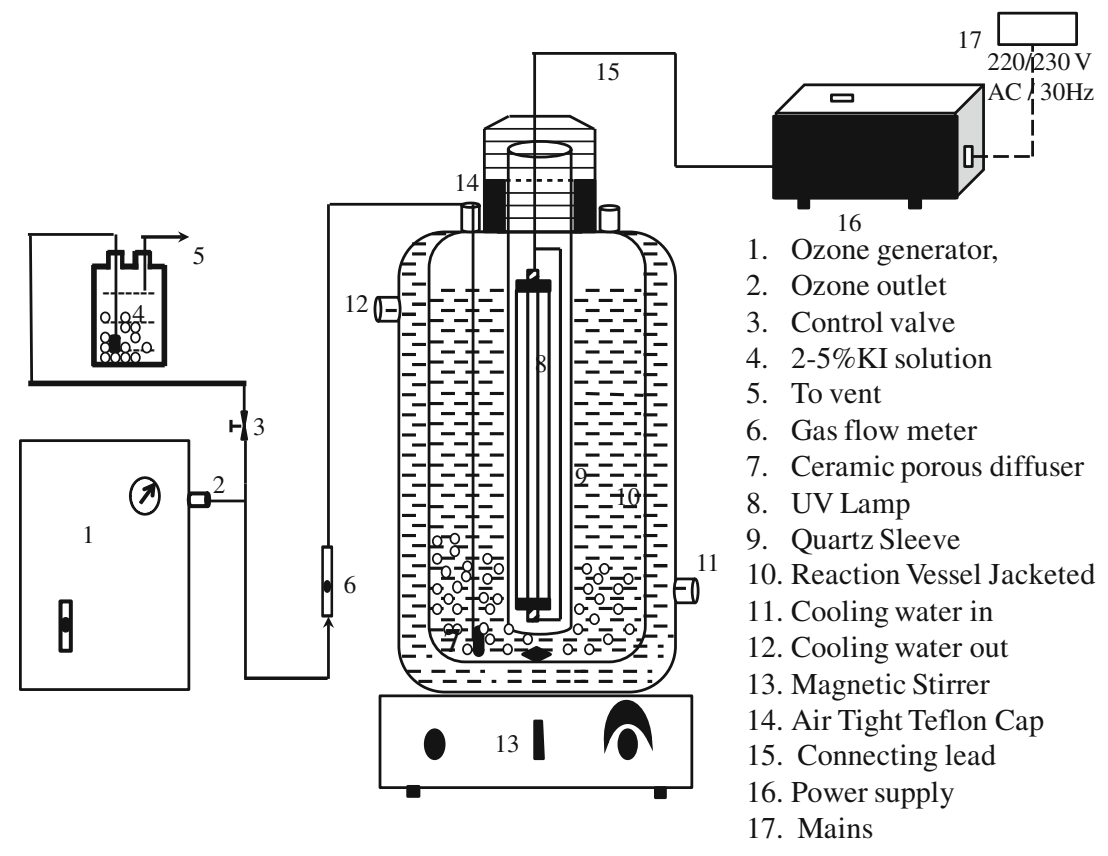

the temperature. The source of UV irradiation is a $16 \mathrm{~W}$ low-pressure mercury vapor lamp with maximum emission of $254 \mathrm{~nm}$ has placed in a quartz tube. The lamp tube is being immersed in the effluent to be treated. The $\mathrm{O}_{3}$ has been generated from the laboratory scale $\mathrm{O}_{3}$ generator (Ozoneteck, Chennai) and bubbled through the distillery effluent at the bottom of the photochemical reactor through a ceramic diffuser. Ozone gas-flow rate and concentration are being controlled at $3 \mathrm{~L} / \mathrm{min}$ and $2 \mathrm{~g} \backslash \mathrm{h} . \mathrm{O}_{3}$ concentrations are determined using an iodometeric method. All the experiments are carried out for $4 \mathrm{~h}$, and samples are collected at different time intervals and quenched with $\mathrm{Na}_{2} \mathrm{SO}_{3}$ to arrest the reaction. Then, the sample is filtered using a Whatman 40 filter paper. To determine color removal, UV-Visible absorbance is used with the fixed wavelength $(\lambda=290 \mathrm{~nm})$ and the COD of the samples is determined using the dichromatic closed reflux method, strictly following the APHA (1995). The effluent COD concentration has been diluted using water and brings to $1,500 \mathrm{mg} \backslash \mathrm{L}$ for the experiment.

The energy consumption was also determined using the following formula. Electrical energy per order determination for the AOPs can be calculated by the following equation.

$$
\mathrm{EE} / \mathrm{O}=\frac{P_{\mathrm{el}} \times t \times 1000}{V \times 60 \times \log \left(\frac{C_{\mathrm{i}}}{C_{\mathrm{f}}}\right)}
$$

where EE/O is the electrical energy per order $\left(\mathrm{kWh} / \mathrm{m}^{3}\right.$ $\left.\operatorname{order}^{1}\right), P_{\mathrm{el}}$ is the electrical power input $(\mathrm{kW}), t$ is the irradiation time (min), $V$ is the volume of effluent used (L), $C_{\mathrm{i}}$ and $C_{\mathrm{f}}$ is the initial and final effluent concentration (ppm).

The decolorization and degradation of distillery industry effluent was investigated using the pseudo-first-order kinetic model, as shown in Eq. (2)

$\log \left(\frac{C_{\mathrm{i}}}{C_{\mathrm{f}}}\right)=k t$

$k$ is the pseudo-first-order rate constant for the decay of the effluent concentration $\left(\mathrm{min}^{-1}\right)$.

Combining the above two equation simply gives an equation for the electrical energy determination in the form

$\mathrm{EE} / \mathrm{O}=\frac{38.4 * P_{\mathrm{el}}}{V * k}$

\section{Results and discussion}

$\mathrm{UV} / \mathrm{H}_{2} \mathrm{O}_{2}$ process

In this process, influence of hydrogen peroxide concentration and $\mathrm{pH}$ on percentage color and COD removal of the distillery effluent has been studied. The concentration of $\mathrm{H}_{2} \mathrm{O}_{2}$ is an important factor affecting the performance of the process, and the amount is directly connected to the generation of hydroxyl radi- 


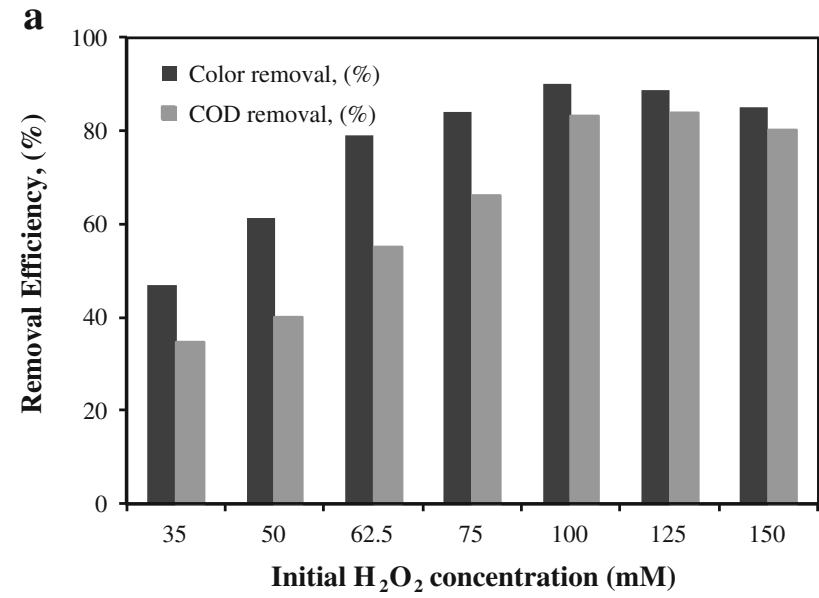

b

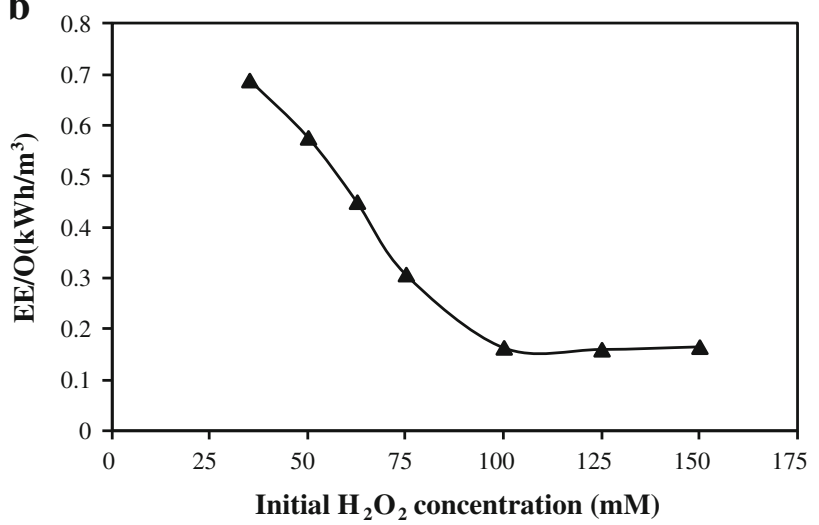

Fig. 2 a Effect of $\mathrm{H}_{2} \mathrm{O}_{2}$ concentration on color, COD removal and b electric energy per order in $\mathrm{UV} / \mathrm{H}_{2} \mathrm{O}_{2}$ process. (Experimental conditions: initial COD concentration: $1,500 \mathrm{ppm}$; initial $\mathrm{pH} 7$; UV lamp: $16 \mathrm{~W}$ and $254 \mathrm{~nm}$; time: $240 \mathrm{~min}$ )

cals. The effect of $\mathrm{H}_{2} \mathrm{O}_{2}$ concentration on the percentage color and COD removal for the distillery effluent is shown in Fig. 2a with an initial effluent COD concentration of $1,500 \mathrm{mg} \backslash \mathrm{L}$ for the irradiation time of $4 \mathrm{~h}$. It can be noticed from the figure, the concentration of $\mathrm{H}_{2} \mathrm{O}_{2}$ increases from 35 to $100 \mathrm{mM}$, the decolorization and COD removal are increased from 46.9 to $90 \%$ and 34.8 to $83.3 \%$, respectively. However, when the $\mathrm{H}_{2} \mathrm{O}_{2}$ dosage increased above $100 \mathrm{mM}$, the decolorization and COD removal efficiency have been decreased slightly. This is may be due to the fact that at higher concentration of $\mathrm{H}_{2} \mathrm{O}_{2}$ scavenging of $\mathrm{HO}^{\circ}$ radicals will occur. The similar mechanism has been reported by Yuan et al. (2012). The following reaction shows (Gul and Yildirim 2009) hydrogen peroxide scavenging of $\mathrm{HO}^{\circ}$ radicals.

$$
\mathrm{H}_{2} \mathrm{O}_{2}+\mathrm{HO}^{\cdot} \rightarrow \mathrm{HO}_{2}^{-}+\mathrm{H}_{2} \mathrm{O}
$$
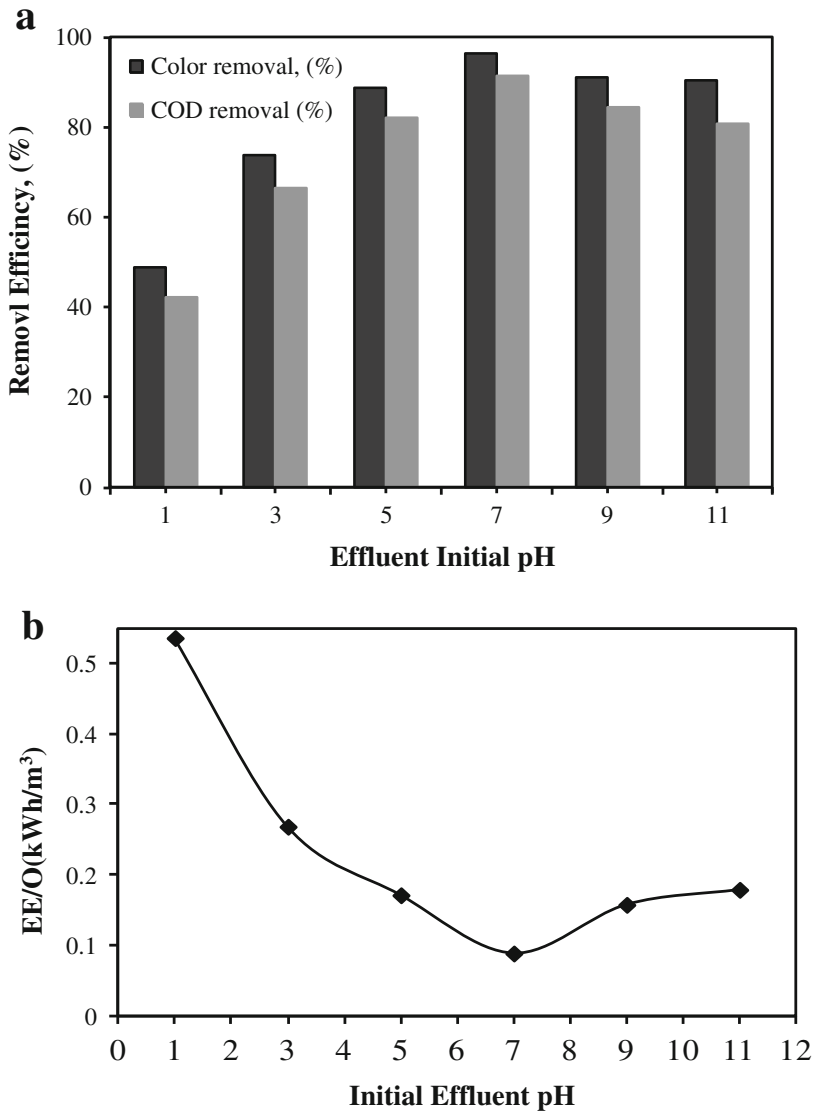

Fig. 3 a Effect of effluent $\mathrm{pH}$ on color, COD removal and $\mathbf{b}$ electric energy per order in $\mathrm{UV} / \mathrm{H}_{2} \mathrm{O}_{2}$ process. (Experimental conditions: initial COD concentration: $1,500 \mathrm{ppm}, \mathrm{H}_{2} \mathrm{O}_{2}: 100 \mathrm{mM}$, UV lamp: $16 \mathrm{~W}$ and $254 \mathrm{~nm}$; time: $240 \mathrm{~min}$ )

$\mathrm{HO}_{2}+\mathrm{HO}^{\prime} \rightarrow \mathrm{H}_{2} \mathrm{O}+\mathrm{O}_{2}$

It is important to remark that $\mathrm{HO}_{2}$ is less reactive than $\mathrm{HO}$, and thus an increased amount of $\mathrm{H}_{2} \mathrm{O}_{2}$ has diminishing the $\mathrm{HO}$ formation. To achieve higher degradation and decolorization rate, the concentration of $\mathrm{H}_{2} \mathrm{O}_{2}$ should be at optimum dosage. The electrical energy per order was calculated based on the various concentration of $\mathrm{H}_{2} \mathrm{O}_{2}$ used as shown in Fig. 2b. The electrical energy per order is decreased from 0.6895 to $0.1645 \mathrm{kWh} / \mathrm{m}^{3}$ with increasing initial $\mathrm{H}_{2} \mathrm{O}_{2}$ concentration from 35 to $125 \mathrm{mM}$, it is due to the generation of more and more $\mathrm{OH}$ radicals; however, electrical energy per order tends to increase slightly with increasing initial concentration of $\mathrm{H}_{2} \mathrm{O}_{2}$ above $125 \mathrm{mM}$, the reason may be due to coincident $\mathrm{OH}$ consumption at high $\mathrm{H}_{2} \mathrm{O}_{2}$ concentrations (Saien et al. 2012).

The effect of initial effluent $\mathrm{pH}$ on the decolorization and COD removal of distillery effluent is shown in 


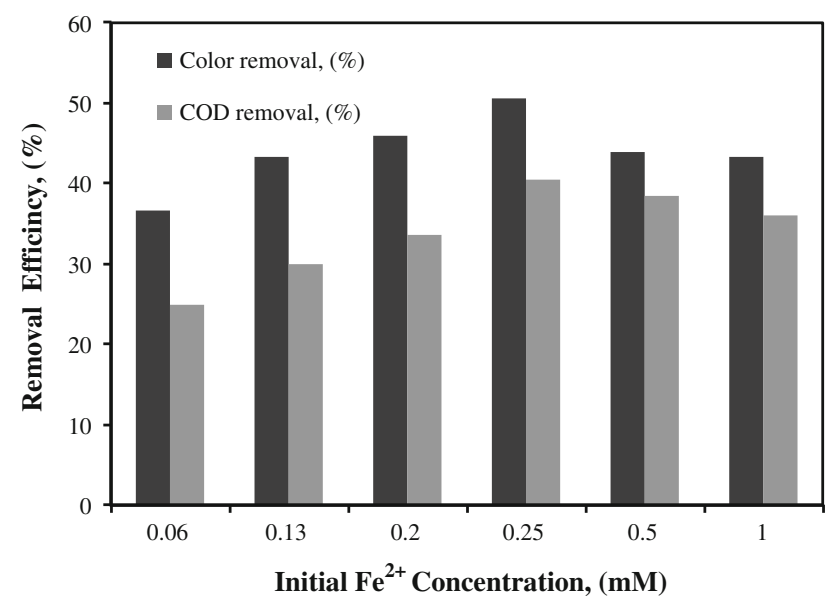

Fig. 4 Effect of $\mathrm{Fe}^{2+}$ concentration on color and $\mathrm{COD}$ removal in $\mathrm{H}_{2} \mathrm{O}_{2} / \mathrm{Fe}^{2+}$ process. (Experimental conditions: initial COD concentration: 1,500 ppm, $\mathrm{H}_{2} \mathrm{O}_{2}: 100 \mathrm{mM}$, effluent $\mathrm{pH} \mathrm{3,} \mathrm{time:} 240 \mathrm{~min}$ )

Fig. 3a for the system of $\mathrm{UV} / \mathrm{H}_{2} \mathrm{O}_{2}$. It is observed from the figure that $\mathrm{pH}$ increases from 1 to 7 the percentage color and COD removal increased from 48.78 to $96.43 \%$ and 42.3 to $91.59 \%$, respectively. Further increasing the $\mathrm{pH}$ from 7 to 11 , color and COD removal percentage decreased from 96.43 to $90.5 \%$ and 91.59 to $80.76 \%$, respectively. Increasing of $\mathrm{pH}$ yielded two opposing effects: one the generation of more hydroxyl radical since the molar extinction coefficient of hydroperoxide anion $\left(\mathrm{HO}_{2}{ }^{-}\right)$, the ionic form of $\mathrm{H}_{2} \mathrm{O}_{2}$ at high $\mathrm{pH}$, was higher than that of $\mathrm{H}_{2} \mathrm{O}_{2}$ and the other the hydroperoxide anion $\left(\mathrm{HO}_{2}{ }^{-}\right)$could also scavenge the hydroxyl radicals by the following equation (Poyatos et al. 2010).

$\mathrm{HO}_{2}^{-}+\mathrm{OH} \rightarrow \mathrm{HO}_{2}^{-}+\mathrm{OH}$

The reaction rate of $\mathrm{HO}_{2}{ }^{-}$reacted with $\mathrm{OH}$ was faster than that of $\mathrm{H}_{2} \mathrm{O}_{2}$, the scavenging rate of $\mathrm{OH}$ was also increased with $\mathrm{pH}$ increased. Finally, the comparisons with the $\mathrm{pH}$ effect, neutral and weak alkaline solution were more suitable to carry out the $\mathrm{UV} / \mathrm{H}_{2} \mathrm{O}_{2}$ oxidation reaction. Electrical energy per order has studied with an initial COD concentration of $1,500 \mathrm{ppm}, 100 \mathrm{mM}$ of $\mathrm{H}_{2} \mathrm{O}_{2}$ concentration with irradiation of time $4 \mathrm{~h}$ for different $\mathrm{pH}$ is shown in Fig. 3b. It can be observed form the figure, the electrical energy per order is decreased from 0.5358 to $0.08845 \mathrm{kWh} / \mathrm{m}^{3}$ order with increasing initial effluent $\mathrm{pH}$ from 1 to 7 . Hence, increasing the initial effluent $\mathrm{pH}$ from 7 to 11 , the electrical energy per order also increases from 0.08845 to $0.1787 \mathrm{kWh} / \mathrm{m}^{3}$ order. The above results showed that neutral conditions produce more hydroxyl radicals compared with acid and alkali condition.
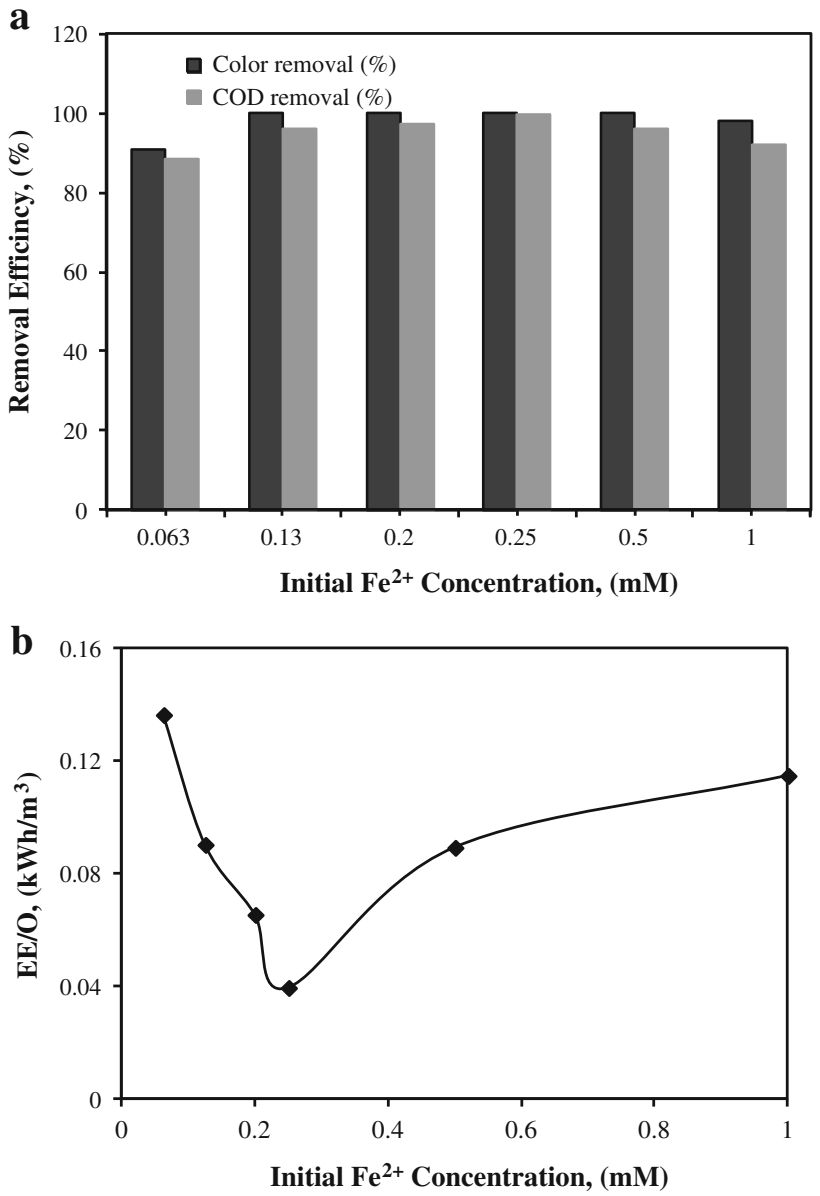

Fig. 5 a Effect of $\mathrm{Fe}^{2+}$ concentration on color, COD removal and b electric energy per order in $\mathrm{UV} / \mathrm{H}_{2} \mathrm{O}_{2} / \mathrm{Fe}^{2+}$ process. (Experimental conditions: initial COD concentration: $1,500 \mathrm{ppm}, \mathrm{H}_{2} \mathrm{O}_{2}$ : $100 \mathrm{mM}$, effluent $\mathrm{pH} 3$, UV lamp: $16 \mathrm{~W}$ and $254 \mathrm{~nm}$, time: $240 \mathrm{~min}$ )

\section{Photo-Fenton system}

The Fenton process is an economically feasible and attractive method for the treatment of industrial effluents. Figure 4 shows the effect of $\mathrm{Fe}^{2+}$ concentration on percentage color and COD removal for the Fenton process. It can be observed from Fig 4, the color and COD removal increases with increase in $\mathrm{Fe}^{2+}$ concentration from 0.06 to $0.25 \mathrm{mM}$. This is due to the fact that $\mathrm{Fe}^{2+}$ acts as a catalyst in the Fenton process. But by further increasing the concentration of $\mathrm{Fe}^{2+}$ above $0.25 \mathrm{mM}$, the percentage color and $\mathrm{COD}$ removal decreases because of $\mathrm{Fe}^{2+}$ acting as selfscavengers and also iron precipitation occur. The effect of $\mathrm{Fe}^{2+}$ concentration on color and COD removal for the $\mathrm{UV} / \mathrm{H}_{2} \mathrm{O}_{2} / \mathrm{Fe}^{2+}$ system is shown in Fig. 5a. It can be ascertained from the figure, color and COD removal increases with increase in $\mathrm{Fe}^{2+}$ concentration from 0 to 


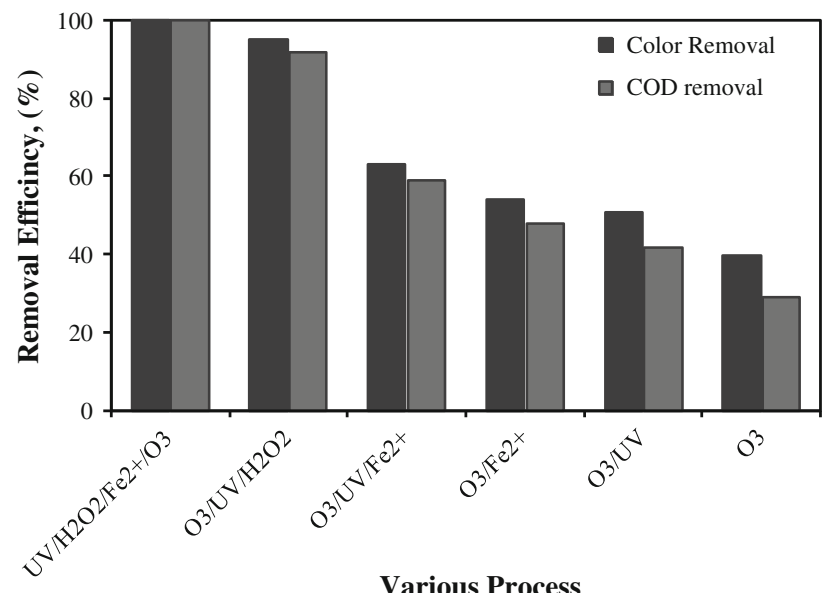

Fig. 6 Comparison of ozone with various processes on color and COD removal

$0.25 \mathrm{mM}$. By increasing the concentration from 0.25 to $1 \mathrm{mM}$, the color and COD removal decreases. This is due to the addition of large amounts of $\mathrm{Fe}^{2+}$ ions can function as direct scavengers of hydroxyl radicals by increasing the rate of formation of $\mathrm{H}_{2} \mathrm{O}$ radicals. The effect of initial $\mathrm{Fe}^{2+}$ concentration on electrical energy per order is shown in Fig. 5b. Experiments are conducted by varying $\mathrm{Fe}^{2+}$ from 0.0625 to $1 \mathrm{mM}$ with an initial COD concentration of $1,500 \mathrm{ppm}, 100 \mathrm{mM}$ of $\mathrm{H}_{2} \mathrm{O}_{2}$ concentration with irradiation of time $4 \mathrm{~h}$. When the concentration of $\mathrm{Fe}^{2+}$ is increased from 0.0625 to $0.25 \mathrm{mM}$, the electrical energy per order decreased from 0.1365 to $0.039737 \mathrm{kWh} / \mathrm{m}^{3}$ order. Further increasing the initial concentration of $\mathrm{Fe}^{2+}$ from 0.25 to $1 \mathrm{mM}$, the electrical energy per order increase from 0.039737 to $0.11491 \mathrm{kWh} / \mathrm{m}^{3}$ order $^{1}$. The above results indicating that optimum conditions of $\mathrm{Fe}^{2+}$ and $\mathrm{H}_{2} \mathrm{O}_{2}$ with irradiation process to produce more hydroxyl radicals compared with other conditions.

UV-ozone process

Ozone is a strong oxidants having the potential of $2.08 \mathrm{~V}$, reacts with organic directly or indirectly. Previous research has proved that ozone alone degrades the pollutant less effectively. Hence, ozone combined with AOPs will degrade the pollutant effectively and efficiently. AOP using
Table 2 Comparison various AOP

\begin{tabular}{llll}
\hline $\begin{array}{l}\text { Various } \\
\text { process }\end{array}$ & $\begin{array}{l}\text { Color } \\
\text { removal } \\
(\%)\end{array}$ & $\begin{array}{l}\text { COD } \\
\text { removal } \\
(\%)\end{array}$ & $\begin{array}{l}\text { Electrical energy } \\
\text { determination } \\
\left(\mathrm{kWh} / \mathrm{m}^{3} \text { order }\right.\end{array}$ \\
\hline $\left.\mathrm{O}_{3}\right)$ \\
$\mathrm{O}_{3} / \mathrm{UV}$ & 39.62 & 29.17 & 0.64 \\
$\mathrm{O}_{3} / \mathrm{Fe}^{2}$ & 50.92 & 41.67 & 1.19 \\
$\mathrm{O}_{3} / \mathrm{UV}^{2} / \mathrm{Fe}^{2+}$ & 53.95 & 48 & 0.64 \\
$\mathrm{H}_{2} \mathrm{O}_{2} / \mathrm{Fe}^{2+}$ & 57.71 & 59 & 0.76 \\
$\mathrm{UV} / \mathrm{H}_{2} \mathrm{O}_{2}$ & 55.97 & 53.85 & - \\
$\mathrm{O}_{3} / \mathrm{UV} / \mathrm{H}_{2} \mathrm{O}_{2}$ & 73.72 & 66.67 & 0.27 \\
$\mathrm{UV} / \mathrm{H}_{2} \mathrm{O}_{2} / \mathrm{Fe}^{2+}$ & 81.72 & 92 & 1.04 \\
$\mathrm{O}_{3} / \mathrm{UV} / \mathrm{Fe}^{2+} / \mathrm{H}_{2} \mathrm{O}_{2}$ & 100 & 99.99 & 0.097 \\
\hline
\end{tabular}

ozone and ultraviolet radiation begins with the photolysis of the ozone, which produces the formation of hydroxyl radical as shown in the following reaction

$\mathrm{O}_{3}+\mathrm{H}_{2} \mathrm{O}+\mathrm{hv} \rightarrow \mathrm{H}_{2} \mathrm{O}_{2}+\mathrm{O}_{2}$

$\mathrm{H}_{2} \mathrm{O}_{2}+\mathrm{hv} \rightarrow 2 \mathrm{OH}$

$\mathrm{H}_{2} \mathrm{O}_{2}+\mathrm{OH}^{-} \rightarrow \mathrm{HO}_{2}^{-}+\mathrm{H}_{2} \mathrm{O}$

The aqueous medium saturated with ozone is radiated with ultraviolet light at a wavelength of $253.7 \mathrm{~nm}$. In this wavelength, the excitation coefficient for gas-phase ozone is $3,300 \backslash \mathrm{M} \backslash \mathrm{cm}$, a value much greater than that of hydrogen peroxide (18.6\M\cm) Poyatos et al. (2010). The Fig. 6 shows the color and COD removal of distillery effluent of various AOPs with ozone process. It can be observed from the figure, ozone alone shows 39.62 and $29.12 \%$ of color removal and COD, respectively. Ozone coupled with photo-Fenton process gave better results of $100 \%$ color and COD removal within $4 \mathrm{~h}$ of reaction process.

Comparisons between various processes

The comparison of different advanced oxidation process is to determine the best color and COD removal performance and the most efficient process for the removal of pollutant. The comparison of various AOPs was reported for the treatment of distillery effluent in Table 2. It is observed from the Table, the color and COD removal of distillery effluent by different AOPs in the descending order as follows: color and $\mathrm{COD}$ removal of $\mathrm{O}_{3}<\mathrm{O}_{3} / \mathrm{UV}<\mathrm{O}_{3}$ / $\mathrm{Fe}^{2+}<\mathrm{O}_{3} / \mathrm{UV} / \mathrm{Fe}^{2+}<\mathrm{H}_{2} \mathrm{O}_{2} / \mathrm{Fe}^{2+}<\mathrm{UV} / \mathrm{H}_{2} \mathrm{O}_{2}<\mathrm{O}_{3} / \mathrm{UV} /$ 
$\mathrm{H}_{2} \mathrm{O}_{2}<\mathrm{UV} / \mathrm{H}_{2} \mathrm{O}_{2} / \mathrm{Fe}^{2+}<\mathrm{O}_{3} / \mathrm{UV} / \mathrm{Fe}^{2+} / \mathrm{H}_{2} \mathrm{O}_{2}$. The electrical energy per order of the various processes is also shown in Table 2. It can be observed that higher electrical energy per order values corresponding to lower efficiency of the system and the founded electrical energy per order $(\mathrm{kWh} /$ $\mathrm{m}^{3}$ order $^{1}$ ) values in the decreasing order are $\mathrm{O}_{3} / \mathrm{UV}<\mathrm{O}_{3} /$ $\mathrm{UV} / \mathrm{H}_{2} \mathrm{O}_{2}<\mathrm{O}_{3} / \mathrm{UV} / \mathrm{Fe}^{2+}<\mathrm{O}_{3}<\mathrm{O}_{3} / \mathrm{Fe}^{2+}<\mathrm{UV} / \mathrm{H}_{2} \mathrm{O}_{2}<$ $\mathrm{UV} / \mathrm{H}_{2} \mathrm{O}_{2} / \mathrm{Fe}^{2+}<\mathrm{O}_{3} / \mathrm{UV} / \mathrm{Fe}^{2+} / \mathrm{H}_{2} \mathrm{O}_{2}$. However, the selection of the process based on economical aspect, required equipments, operational problems, secondary pollutants and energy consumption etc. From the study the lowest energy consumption for highest pollutant removal is observed for $\mathrm{O}_{3} / \mathrm{UV} / \mathrm{Fe}^{2+} / \mathrm{H}_{2} \mathrm{O}_{2}$ process. Hence, this process can be applied for the treatment of industrial effluent.

\section{Conclusion}

In this investigation, treatment of distillery effluent has been studied using various advance oxidation process such as $\mathrm{UV} / \mathrm{H}_{2} \mathrm{O}_{2}, \mathrm{H}_{2} \mathrm{O}_{2} / \mathrm{Fe}^{2+}, \mathrm{UV} / \mathrm{H}_{2} \mathrm{O}_{2} / \mathrm{Fe}^{2+}, \mathrm{O}_{3}, \mathrm{O}_{3} / \mathrm{Fe}^{2+}, \mathrm{O}_{3} /$ $\mathrm{UV}, \mathrm{O}_{3} / \mathrm{UV} / \mathrm{H}_{2} \mathrm{O}_{2}, \mathrm{O}_{3} / \mathrm{UV} / \mathrm{Fe}^{2+}$ and $\mathrm{O}_{3} / \mathrm{UV} / \mathrm{Fe}^{2+} / \mathrm{H}_{2} \mathrm{O}_{2}$. Effect of various operating parameter has been studied extensively for the color and COD removal for the distillery effluent. Electrical energy per order was also evaluated for the various AOP for the distillery effluent treatment. It can be concluded for the investigation that individual process performs less efficiently for the treatment of effluent, and if it is coupled with ozone and photoFenton process, it performs more efficiently than the individual process. For the present process, $\mathrm{O}_{3} / \mathrm{UV} / \mathrm{Fe}^{2+}$ / $\mathrm{H}_{2} \mathrm{O}_{2}$ shows $100 \%$ color and COD removal with the lesser energy consumption of $0.01 \mathrm{kWh} / \mathrm{m}^{3}$ order $^{1}$ compared with all other process. Hence, AOP process will be a suitable process for the treatment of highly organic effluents.

Acknowledgments The authors would like express their sincere thanks to the Department of Chemical Engineering, National Institute of Technology, Tiruchirappalli, for providing the technical assistance to carry out the work.

\section{References}

APHA, AWWA and WPCF (1995) Standard method for examination of water and wastewater, 19th edn. APHA, AWWA and WPCF, Washington

Asaithambi P, Susree M, Saravanathamizhan R, Matheswaran M (2012) Ozone assisted electrocoagulation for the treatment of distillery effluent. Desalination 297:1-7
Bali U, Catalkaya E, Sengul F (2004) Photodegradation of reactive black 5, direct red 28 and direct yellow 12 using $\mathrm{UV}, \mathrm{UV} / \mathrm{H}_{2} \mathrm{O}_{2}$ and $\mathrm{UV} / \mathrm{H}_{2} \mathrm{O}_{2} / \mathrm{Fe}^{2+}$ : comparative study. J Hazard Mater B 114:159-166

Bin AK, Sobera-Made S (2012) Comparison of the advanced oxidation processes ( $\mathrm{UV}, \mathrm{UV} / \mathrm{H}_{2} \mathrm{O}_{2}$ and $\mathrm{O}_{3}$ ) for the removal of antibiotic substances during wastewater treatment. Ozone Sci Eng 3:136-139

Gul S, Yildirim OO (2009) Degradation of reactive red 194 and reactive yellow 145 azo dyes by $\mathrm{O}_{3}$ and $\mathrm{H}_{2} \mathrm{O}_{2} / \mathrm{UV}-\mathrm{C}$ processes. Chem Eng J 155:684-690

Lucas MS, Peres JA, Puma GL (2010) Treatment of winery wastewater by ozone-based advanced oxidation processes $\left(\mathrm{O}_{3}\right.$, $\mathrm{O}_{3} / \mathrm{UV}$ and $\mathrm{O}_{3} / \mathrm{UV} / \mathrm{H}_{2} \mathrm{O}_{2}$ ) in a pilot-scale bubble column reactor and process economics. Sep Purif Technol 72:235-241

Mandal T, Maity S, Dasgupta D, Datta S (2010) Advanced oxidation process and bio treatment: their roles in combined industrial wastewater treatment. Desalination 250:87-94

Mohanakrishna G, Venkata Mohan S, Sarma PN (2010) Bioelectrochemical treatment of distillery wastewater in microbial fuel cell facilitating decolorization and desalination along with power generation. J Hazard Mater 177:487-494

Nataraj SK, Hosamani KM, Aminabhavi TM (2006) Distillery wastewater treatment by the membrane-based nanofiltration and reverse osmosis processes. Water Res 40:2349-2356

Piya-areetham P, Shenchunthichai K, Hunsom M (2006) Application of electrooxidation process for treating concentrated wastewater from distillery industry with a voluminous electrode. Water Res 40:2857-2864

Ponselvan FIA, Kumar M, Malviya JR, Srivastava VC, Mall ID (2009) Electrocoagulation studies on treatment of biodigester effluent using aluminum electrodes. Water Air Soil Pollut 199:371-379

Poyatos JM, Munio MM, Almecija MC, Torres JC, Hontoria E, Osorio F (2010) Advanced oxidation processes for wastewater treatment: state of the art. Water Air Soil Pollut 205:187-204

Rai UK, Muthukrishnan M, Guha BK (2008) Tertiary treatment of distillery wastewater by nanofiltration. Desalination 230:70-78

Saien J, Moradi V, Soleymani AR (2012) Investigation of a jet mixing photo-reactor device for rapid dye discoloration and aromatic degradation via $\mathrm{UV} / \mathrm{H}_{2} \mathrm{O}_{2}$ process. Chem Eng J 183:135-140

Saritha P, Aparna C, Himabindu V, Anjaneyulu Y (2007) Comparison of various advanced oxidation processes for the degradation of 4-chloro-2 nitrophenol. J Hazard Mater 149:609-614

Satyawali Y, Balakrishnan M (2007) Removal of color from biomethanated distillery spentwash by treatment with activated carbons. Bioresour Technol 98:2629-2635

Sreethawong T, Chavadej S (2008) Color removal of distiller wastewater by ozonation in the absence and presence of immobilized iron oxidecatalyst. J Hazard Mater 155:486-493

Thakur C, Srivastava VC, Mall ID (2009) Electrochemical treatment of a distillery wastewater: parametric and residual study. Chem Eng J 148:496-505

Vineetha MN, Matheswaran M, Sheeba KN (2013) Photocatalytic colour and COD removal in the distillery effluent by the solar radiation. Sol Energy 91:368-373

Grcic I, Vujevic D, Koprivanac N (2010) Statistical Evaluation of $\mathrm{UV} / \mathrm{TiO}_{2} / \mathrm{H}_{2} \mathrm{O}_{2}$ and $\mathrm{Fe}^{2+} / \mathrm{H}_{2} \mathrm{O}_{2}$ process for the treatment of coloured wastewater; A comparative study. Chem Biochem Eng Q 24:387-400 
Yuan H, Zhang Y, Zhou X (2012) Degradation of bezafibrate with $\mathrm{UV} / \mathrm{H}_{2} \mathrm{O}_{2}$ in surface water and wastewater treatment plant effluent. Clean: Soil, Air, Water 40:239-245
Zhang W, Xiong R, Wei G (2009) Biological flocculation treatment on distillery wastewater and recirculation of wastewater. J Hazard Mater 172:1252-1257 